\title{
Pemanfaatan E-Book Sebagai Sumber Belajar Mandiri bagi Siswa SMK/SMK/MA
}

\author{
Ela Suryani ${ }^{*}{ }^{*}$, Ika Silfiana Arifatul Khoiriyah ${ }^{2}$
}

1,2 Universitas Ngudi Waluyo

A R T I C L E I N F O

Article history:

Received 15 March 2018

Received in revised form 10 May 2018

Accepted 30 June2018

Available online 26 August 2018

Kata Kunci:

e-book, sumber belajar

mandiri

Keywords:

e-book, independent

learning resource

\begin{abstract}
A B S T R A K
Kegiatan pengabdian kepada masyarakat di SMA/SMK/MA ditujukan untuk mensosialisasikan pemanfaatan e-book kepada siswa kelas XII. Subyek dari PkM ini berjumlah 60 siswa dengan 2 obyek di SMA N 1 Pabelan (40 siswa) dan SMK Kanaan (20 siswa). Metode pelaksanaan yang digunakan adalah presentasi brainstorming, dan sharing tentang e-book melalui lembar angket. Teknik pengumpulan data menggunakan lembar kuesioner dan lembar observasi berdasarkan demonstrasi yang dilakukan. Kegiatan PkM ini dilaksanakan melalui sosialisasi, pendampingan, dan monitoring dan evaluasi. Pelaksanaan PkM pemanfaatan e-book kepada siswa kelas XII SMA N 1 Pabelan dan SMK Kanaan mampu meningkatkan pemahaman terhadap e-book yang ditandai dengan persentase indikator ketercapaian memahami e-book (93\%), mengunduh e-book (51\%), dan menggunakan e-book (80\%). Tanggapan positif dari siswa kelas XII SMA N 1 Pabelan dan SMK Kanaan terhadap pelaksanaan
\end{abstract} kegiatan PkM ini tergolong sangat baik. Hal ini dapat dilihat dari indikator kehadiran peserta PkM mencapai $98 \%$ dari target dan selama kegiatan berlangsung peserta sangat antusias mengikuti kegiatan dari awal sampai akhir kegiatan. Implikasi PkM yang dapat digunakan oleh khalayak umum adalah e-book dapat digunakan sebagai sumber belajar mandiri bagi siswa yang tidak memiliki buku cetak dan dapat dijadikan referensi alternative/tambahan bagi guru apabila kekurangan jumlah tatap muka di kelas namun materi yang disampaikan tidak terdapat di buku cetak sekolah.

\section{A B S T R A C T}

Community service activities in high school / vocational / MA are aimed at socializing the use of e-books to class XII students. The subjects of this PKM are 60 students with 2 objects in SMA N 1 Pabelan (40 students) and Kanaan Vocational School (20 students). The implementation method used is a brainstorming presentation, and sharing about e-books through questionnaire sheets. Data collection techniques used questionnaire sheets and observation sheets based on the demonstration carried out. The PKM activities are carried out through socialization, mentoring, and monitoring and evaluation. The implementation of PkM utilizing e-books to class XII students of SMA N 1 Pabelan and Kanaan Vocational School was able to improve understanding of e-books which was marked by the percentage of indicators of understanding e-books (93\%), downloading e-books (51\%), and using ebook (80\%). Positive responses from class XII students of SMA N 1 Pabelan and Kanaan Vocational School towards the implementation of PKM activities are classified as very good. This can be seen from the indicator of the attendance of PkM participants reaching $98 \%$ of the target and during the activity the participants were very enthusiastic about participating in the activity from the beginning to the end of the activity. The implication of PKM that can be used by the general public is that the ebook can be used as a source of independent learning for students who do not have printed books and can be used as an alternative / additional reference for teachers if there is a lack of face-to-face classes but not in printed books school.

\footnotetext{
* Corresponding author.

E-mail addresses: ela.suryani16@gmail.com (Ela Suryani)
} 


\section{Pendahuluan}

Keberhasilan proses pembelajaran merupakan hal utama yang diharapkan dalam pelaksanaan pendidikan di sekolah. Dalam proses pembelajaran, komponen utama adalah guru dan siswa. Supaya proses pembelajaran berhasil, guru harus membimbing siswa sedemikian rupa sehingga siswa dapat mengembangkan pengetahuan sesuai dengan struktur bidang yang dipelajarinya. Salah satu usaha untuk mengatasi keadaan tersebut adalah penggunaan sumber belajar dalam proses pembelajaran.

Berdasarkan hasil penyebaran angket kepada siswa kelas XII SMA N 1 Pabelan dan SMK Kanaan diperoleh informasi bahwa dalam proses pembelajaran di kelas guru lebih sering menggunakan bahan ajar seperti buku paket. Penggunaan bahan ajar lain seperti media pembelajaran atau bahan ajar elektronik masih kurang dimanfaatkan, padahal persediaan buku paket di sekolah sebenarnya masih terbatas dan tidak semua siswa memiliki pegangan buku paket. Terbatasnya persediaan bahan ajar yang dimiliki siswa mengakibatkan proses pembelajaran tidak berjalan secara maksimal. Hal ini didukung bahwa sebanyak $90 \%$ siswa tidak memiliki sumber belajar berupa buku cetak pada tiap mata pelajaran karena siswa hanya membeli buku yang dirasa mata pelajaran itu sulit. Siswa terkendala dengan harga buku cetak yang mahal dan orangtua tidak mampu membelikannya. Hal ini menyebabkan siswa tidak mampu belajar secara mandiri di rumah.

Pembelajaran di kelas XII dengan jumlah jam tatap muka yang terbatas maka penguasaan materi menjadi lebih sulit. Materi yang harus dikuasai siswa untuk belajar secara mandiri di luar jam sekolah masih banyak namun tidak semua siswa memiliki sumber belajar yang lengkap. Oleh karena itu, supaya pembelajaran mandiri berlangsung efektif maka guru harus mempersiapkan sumber belajar yang dapat mengarahkan siswa dalam belajar mandirinya tersebut. Mengatasi permasalahan tersebut maka e-book dapat digunakan sebagai sumber belajar mandiri yang bisa dimanfaatkan oleh siswa. E-book ini dikemas untuk siswa supaya dapat belakar secara mandiri di rumah. Seperti yang dilakukan Koriaty \& Manggala (2016) dan Hasbiyati \& Khusna (2017) bahwa e-book dapat meningkat minat belajar siswa. Hal ini memperkuat bahwa siswa yang memanfaatkan $e$-book sebagai sumber belajar akan memiliki ketertarikan dalam belajar sehingga kemauan untuk belajar mandiri di rumah juga akan meningkat.

Salah satu upaya yang dapat digunakan untuk membantu mengatasi permasalahan siswa dalam memiliki sumber belajar yaitu dengan memnfaatkan suatu bahan ajar berupa buku elektronik (e-book) yang nantinya dapat digunakan siswa baik dalam pembelajaran di sekolah maupun secara mandiri. Akan tetapi, sumber belajar yang sering digunakan guru adalah buku yang berbentuk cetakan. Padahal terdapat buku cetak dalam bentuk digital ( $e$-book) namun jarang digunakan.

Ketika dikroscek ulang, siswa belum pernah menggunakan $e$-book sebagai sumber belajar mandiri padahal sebanyak 91,7\%. Hal ini didukung data siswa kelas XII SMA N 1 Pabelan yang sudah mengetahui e-book hanya sebanyak 10\% (4 anak) sedangkan siswa SMK Kanaan sebanyak 10\% (2 anak). Selain itu, yang sudah pernah mengunduh e-book hanya 5\% (2 anak SMA N 1 Pabelan dan 1 anak SMK Kanaan). Siswa yang menggunakan e-book hanya 3,75\% dengan rincian 25\% (1 anak) siswa SMA N 1 Pabelan dan 2,5\% (1 anak) siswa SMK Kanaan. Hal inilah yang mendasari perlunya kegiatan PkM pemanfaatan e-book sebagai sumber belajar mandiri yang diharapkan dapat memberi pengaruh positif bagi siswa kelas XII untuk memperdalam materi pelajaran dan mempersiapkan UN.

Pemanfaatan e-book merupakan salah satu alternatif pemecahan permasalahan pendidikan melalui aspek penerapan teknologi dengan mendayagunakan sumber-sumber belajar yang dirancang, dikembangkan, dan dimanfaatkan dalam pembelajaran sehingga merangsang terjadinya proses pembelajaran dalam diri siswa secara mandiri (Ragawanto, 2013). E-book inilah yang diperlukan oleh siswa kelas XII tingkat sekolah menengah atas (SMA/SMK/MA) untuk memperdalam materi pelajaran secara mandiri.

Menurut Munif (2013:151) dan Suwarno (2011:74), e-book berbentuk digital dari buku cetak yang umumnya terdiri atas setumpuk kertas dijilid yang berisi teks atau teks dan atau gambar, maka buku elektronik berisikan informasi digital yang dapat berisi teks, gambar, audio, video, yang dapat dibaca di komputer, laptop, tablet, atau smartphone. Secara sederhana e-book sebagai buku elektronik atau buku digital. Buku elektronik adalah versi digital dari buku yang umumnya terdiri dari kumpulan kertas yang berisi teks atau gambar. E-book sebagai buku digital memudahkan masyarakat terutama pelajar yang dapat membaca ratusan halaman buku hanya dalam satu file dan menghemat biaya membeli buku (Probowo \&Heriyanto, 2013). Rosida (2016) dalam kajiannya menyatakan bahwa Keefektifan e-book interaktif yang digunakan dalam pembelajaran untuk menumbuhkan kemampuan berpikir kritis. Andi (2012) berpendapat bahwa E-book memiliki kelebihan dalam hal accessibility, functionality, and costeffectiveness. Oleh karena kelebihan yang ada pada e-book, maka tidak mengherankan jika saat ini banyak di kalangan kaum akademisi menjadikan e-book sebagai salah satu ke dalam pengalaman informasi dan kebiasaan penelitian mereka. Sumber belajar tersebut bukan hanya dalam bentuk bahan cetakan seperti 
buku teks akan tetapi pelajar dapat memanfaatkan sumber belajar yang lain seperti radio pendidikan, televisi, komputer, e-mail, video interaktif, komunikasi satelit, dan teknologi komputer multimedia dalam upaya meningkatkan interaksi dan terjadinya umpan balik dengan peserta didik (Ramli,2012). Sumber informasi yang dapat digunakan sebagai bahan kegiatan penelitian mahasiswa antara lain adalah majalah ilmiah, laporan tahunan, jurnal, prosiding, warta, buletin, dan yang sedang tren saat ini adalah jurnal elektronik (e-journal) dan buku elektronik (e-book) (Lukman, 2014)

Selain itu, berbagai akses e-book dapat mempermudah siswa dalam mengulang atau mereview materi pembelajaran dimana saja dan kapan saja. Akses $e$-book dalam penggunaannya bersifat tertutup hanya dapat dibaca dengan alat dan program khusus. Setiap berkas hanya dapat dibaca dengan perangkat yang disiapkan khusus (e-book reader). Selain itu, e-book yang dapat dibaca oleh berbagai peralatan digital. E-book jenis ini yang tersedia di internet adalah yang untuk dibaca diberbagai alat digital, mulai dari PC desktop, laptop.

Dengan demikian, pendampingan siswa dalam memanfaatkaan e-book sangat diperlukan supaya siswa memiliki pemahaman tentang e-book, cara menggunakan e-book, cara mendapatkan e-book yang pada akhirnya siswa dapat memafaatkan $e$-book yang telah diunduh.

\section{Metode}

Sasaran kegiatan pengabdian kepada masyarakat adalah siswa kelas XII SMA N 1 Pabelan dan SMK Kanaan. Jumlah total sasaran adalah 60 siswa yang terdiri atas 40 siswa SMA N 1 Pabelan dan 20 siswa SMK Kanaan. Siswa SMA N 1 Pabelan tersebut terdiri atas siswa 10 siswa kelas XII IPA1, 10 siswa XII IPA2, 10 siswa XII IPS1, dan 10 siswa XII IPS2 sebagai perwakilan tiap kelasnya. Siswa SMK Kanaan yang berjumlah 20 anak merupakan seluruh siswa kelas XII yang ada di SMK Kanaan,

Metode kegiatan yang dilakukan dalam pengabdian masyarakat ini adalah dengan metode partisipatif artinya mitra binaan secara aktif dilibatkan dalam semua tahapan kegiatan pengabdian masyakat ini. Metode tersebut meliputi presentasi menggunakan powepoint, ceramah, demonstrasi, branstorming, dan sharing.

Kegiatan pengabdian masyarakat ini meliputi tiga kegiatan yaitu : 1) Sosialisasi dilakukan pada tanggal 15 Maret 2018 di SMA N 1 Pabelan dan 17 April 2018 di SMK Kanaan. Kegiatan tersebut membahas tentang bentuk e-book seperti apa, alasan perlunya menggunakan e-book, keunggulan e-book dibandingkan buku cetak, cara mendapatkan e-book, dan contoh e-book yang dapat digunakan siswa sebagai sumber belajar mandiri di sekolah maupun di rumah, 2) Pendampingan dilakukan pada tanggal 19 Maret 2018 di SMA N 1 Pabelan dan 24 April 2018 di SMK Kanaan. Siswa didampingi dalam memanfaatkan e-book sebagai sumber belajar mandiri dengan mengunduh e-book, 3) Monitoring dan evaluasi dilakukan pada tanggal 24 Maret 2018 di SMA N 1 Pabelan dan 8 Mei 2018 di SMK Kanaan. Kegiatan ini bertujuan untuk mem-follow up dari kedua kegiatan di atas.

\section{Hasil dan pembahasan}

Kegiatan PkM yang dilaksanakan dengan metode presentasi, ceramah, demonstrasi, praktik, brainstorming, dan sharing mengenai pemanfaatan e-book berjalan dengan baik dan lancar. Kegiatan ini dilakukan dengan cara tatap muka selama tiga kali pertemuan dengan durasi 2 jam/pertemuan di SMA N 1 Pabelan dan SMK Kanaan.

\section{PkM di SMA N 1 Pabelan}

Kegiatan pertama yaitu sosialisasi yang dilaksanakan dengan jumlah peserta sebanyak 40 anak dengan 5 orang tim pelaksana terdiri atas 2 dosen dan 3 mahasiswa. Pokok bahasan yang disampaikan adalah 1) pengertian $e$-book, 2) alasan menggunakan $e$-book, 3) alamat website yang dapat digunakan untuk mengunduh $e$-book, 4) cara mendapatkan $e$-book, 5) contoh $e$-book.

Kegiatan ini diawali dengan presentasi berupa ceramah interaktif yang dilanjutkan dengan brainstorming dan sharing. Pada awal kegiatan ini terlihat banyak siswa kelas XII yang belum mengetahui $e$-book dan belum pernah melihat bentuk e-book. Siswa hanya mengetahui sumber belajar berasal dari penjelasan guru dan buku cetak berupa cetak.

Siswa dengan antusias mengikuti kegiatan PkM karena e-book menjadi hal yang baru baginya. Siswa mengajukan beberapa pertanyaan terkait pemanfaatan e-book diantaranya 1) apakah semua mata pelajaran terdapat e-book?; 2) dimana alamat website yang dapat mengunduh e-book?. Dengan adanya pertanyaan yang diajukan siswa di atas maka terjadi partisipasi yang aktif antara peserta PkM dengan tim pelaksana. Dari hasil pelaksanaan kegiatan pertama menunjukkan bahwa siswa sudah memahami e-book sebanyak 38 anak dengan presentase 95\%. Hal ini menunjukkan peningkatan pemahaman siswa mengenai $e$-book yang semula hanya $10 \%$. 
Kegiatan kedua yang dilaksanakan dengan peserta berjumlah 37 anak karena 3 anak sebagai atlet mengikuti lomba. Kegiatan kedua ini adalah pendampingan dalam mengunduh $e$-book yang nantinya dapat digunakan sebagai sumber belajar mandiri. Pada saat kegiatan ini, ada 5 siswa yang tidak memiliki kuota internet sehingga tim pelaksana harus melakukan tathering data supaya semua siswa yang mengikuti PkM sudah mampu mengunduh e-book.

Selain itu, terdapat 3 siswa yang ruang penyimpanan handphone sudah penuh sehingga tidak memungkinkan jika siswa tersebut menyimpan e-book di handphone. Dengan demikian, tim pelaksana meminta siswa untuk menghapus beberapa file, akun game, atau foto di galeri handphone yang tidak penting. Hal ini dimaksudkan agar kegiatan pendampingan dan penggunaan $e$-book dapat berjalan lancar.

Hasil kegiatan kedua adalah sebanyak 36 siswa (90\%) sudah mengunduh e-book dan tersimpan di handphone sehingga siswa dapat menggunakan e-book sewaktu-waktu sebagai sumber belajar baik di sekolah maupun di rumah. Siswa mengaku bahwa pertama kali mempunyai buku yang berupa softfile sehingga tidak perlu membawa buku cetak mata pelajaran yang berat. Akan tetapi, buku dari penerbit yang ternama memang tidak bisa diunduh.

Kegiatan ketiga adalah monitoring dan evaluasi (monev) yang dilakukan dalam rangka mem-follow up dari kedua kegiatan yang telah dilakukan sebelumnya. Sebanyak 40 siswa yang menjadi perwakilan kelas dievaluasi terlebih dahulu apakah sudah menggunakan e-book sebagai sumber belajar mandiri. Setelah itu, 10 siswa tiap perwakilan kelas diminta mengkomunikasikan hasil kegiatan PkM terkait pemanfaatan $e$-book kepada semua teman di kelasnya. Hasil ketiga kegiatan yang telah dilakukan kepada siswa kelas XII SMA N 1 Pabelan menunjukkan peningkatan pemahaman mengenai e-book. Peningkatan tersebut dapat terlihat pada persentase pemahaman sebelum dilakukannya kegiatan PkM dan setelah dilakukannya kegiatan PkM yang dapat terlihat pada Tabel 1.

Tabel 1. Peningkatan pemahaman e-book di SMA N 1 Pabelan

\begin{tabular}{lllc}
\hline \multirow{2}{*}{ No. } & \multirow{2}{*}{ Kemampuan yang diamati } & Persentase & \\
\cline { 3 - 4 } & & Sebelum PkM & Setelah PkM \\
\hline 1. & Memahami $e$-book & $10 \%$ & $95 \%$ \\
2. & Mengunduh -book & $5 \%$ & $90 \%$ \\
3. & Menggunakan $e$-book & $2,5 \%$ & $85 \%$ \\
\hline
\end{tabular}

Berdasarkan Tabel 1 menunjukkan siswa kelas XII SMA N 1 Pabelan telah mengalami peningkatan pemahaman, mengunduh, dan menggunakan e-book sebagai sumber belajar mandiri siswa . Hasil kegiatan ini diharapkan dapat digunakan siswa ketika belajar di sekolah maupun di rumah apabila tidak memiliki buku cetak yang berupa cetak.

\section{PkM di SMK Kanaan}

Kegiatan pertama yaitu sosialisasi yang dilaksanakan dengan jumlah peserta 20 siswa. Kegiatan ini diawali dengan presentasi berupa ceramah interaktif mengenai pengertian $e$-book, alasan menggunakan $e$-book, alamat website yang dapat digunakan untuk mengunduh e-book, cara mendapatkan $e$-book, dan contoh $e$-book.. Setelah kegiatan tersebut dilanjutkan brainstorming dan sharing. Banyak siswa kelas yang belum mengetahui e-book dan belum pernah melihat bentuk e-book. Siswa hanya mengetahui buku berupa cetak saja.

Seperti halnya yang dirasakan oleh siswa SMA N 1 Pabelan bahwa siswa SMK Kanaan juga mengikuti kegiatan PkM dengan antusias karena $e$-book menjadi hal yang baru baginya. Siswa mengajukan berbagai macam pertanyaan sehingga interaksi dua arah antara siswa dengan tim pelaksana PkM. Dari hasil pelaksanaan kegiatan pertama menunjukkan bahwa siswa sudah memahami e-book sebanyak 18 anak dengan persentase $90 \%$. Hal ini menunjukkan peningkatan pemahaman siswa mengenai $e$-book yang semula hanya $10 \%$.

Kegiatan kedua yang dilaksanakan dengan jumlah peserta sejumlah 20 anak. Kegiatan kedua ini adalah pendampingan dalam mengunduh e-book dapat digunakan sebagai sumber belajar mandiri bagi siswa SMK Kanaan. Siswa pada saat diminta mengunduh e-book melalui handphone justru membuka akun sosial media dan game bukan membuka alamat website sesuai petunjuk tim pelaksana PkM. Dengan demikian, tim pelaksana menegaskan kembali aturan kegiatan PkM ketika siswa menggunakan handphone di dalam kelas.

Setelah kegiatan kedua ini terlihat sebanyak 15 siswa (75\%) sudah mengunduh e-book dan tersimpan di handphone sehingga siswa dapat menggunakan e-book sewaktu-waktu sebagai sumber belajar baik di sekolah maupun di rumah. Siswa merasa senang telah mempunyai $e$-book beberapa mata 
pelajaran. Siswa berharap semua mata pelajaran di SMK terdapat e-book yang dapat digunakan untuk belajar.

Kegiatan ketiga adalah monitoring dan evaluasi (monev) dilakukan untuk mem-follow up dari kedua kegiatan yang telah dilakukan sebelumnya. Siswa tidak hanya memahami dan mengunduh $e$-book namun siswa telah menggunakan $e$-book untuk sumber belajar di sekolah maupun di rumah. Siswa yang telah menggunakan $e$-book sebanyak 14 siswa dengan persentase $70 \%$.

Hasil ketiga kegiatan yang telah dilakukan kepada siswa kelas XII SMK Kanaan menunjukkan peningkatan pemahaman mengenai e-book. Peningkatan tersebut dapat terlihat pada persentase pemahaman sebelum dilakukannya kegiatan PkM dan setelah dilakukannya kegiatan PkM yang dapat terlihat pada Tabel 2 .

Tabel 2. Peningkatan pemahaman $e$-book di SMK Kanaan

\begin{tabular}{llcc}
\hline \multirow{2}{*}{ No. } & \multirow{2}{*}{ Kemampuan yang diamati } & \multicolumn{2}{c}{ Persentase } \\
\cline { 3 - 4 } & & Sebelum PkM & Setelah PkM \\
\hline 1. & Memahami $e$-book & $10 \%$ & $90 \%$ \\
2. & Mengunduh $e$-book & $5 \%$ & $75 \%$ \\
3. & Menggunakan $e$-book & $5 \%$ & $70 \%$ \\
\hline
\end{tabular}

Siswa kelas XII SMK Kanaan seperti pada Tabel 2 telah mengalami peningkatan pemahaman, mengunduh, dan menggunakan e-book sebagai sumber belajar mandiri siswa. Hasil kegiatan ini diharapkan dapat digunakan siswa ketika belajar di sekolah maupun di rumah apabila tidak memiliki buku cetak yang berupa cetak.

Dengan demikian, kegiatan PkM di kedua mitra mengalami peningkatan pemahaman, mengunduh, dan menggunakan e-book. berdasarkan Tabel 1 dan Tabel 2. Apabila direkapitulasi peningkatannya dapat terlihat pada Gambar 1 di bawah ini.

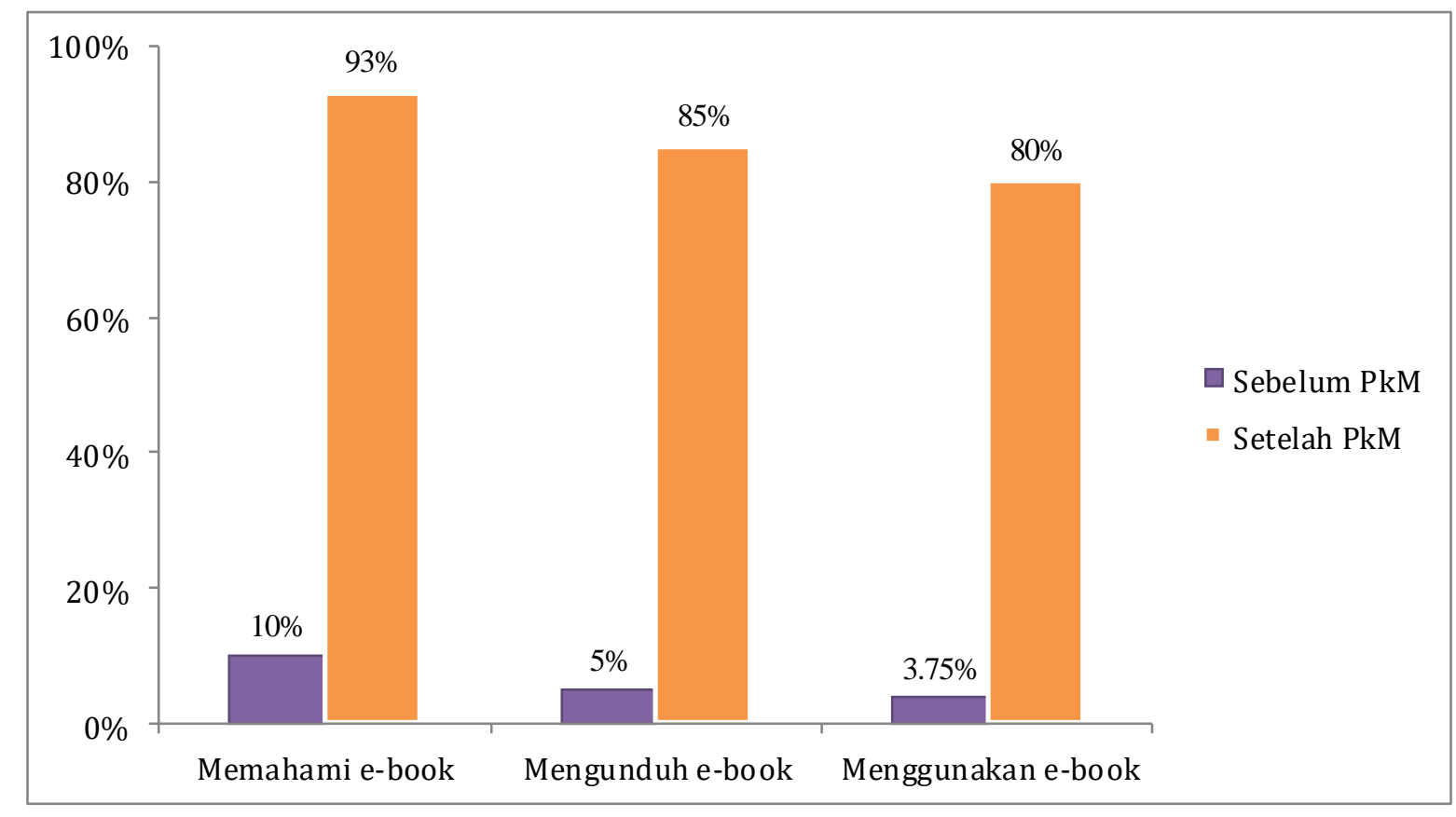

Gambar 1. Peningkatan pemahaman e-book setelah PkM

Kegiatan pengabdian kepada masyarakat yang telah dilakukan tim pelaksana mendapat respon positif dari kedua mitra yaitu SMA N 1 Pabelan dan SMK Kanaan. Hal ini terlihat dari siswa yang antusias mengikuti kegiatan PkM dan hasil kegiatan juga dalam kategori sangat baik. Sebelum adanya kegiatan PkM ini, siswa menggunakan handphone android hanya diisi dengan akun game dan sosial media saja. Siswa belum ada yang menyimpan e-book di handphone miliknya.

Oleh karena itu, pemanfaatan e-book merupakan salah satu alternatif pemecahan permasalahan pendidikan yang siswanya memiliki handphone namun tidak dipergunakan sebagai sumber belajar. Apabila dilihat dari aspek penerapan teknologi dengan mendayagunakan sumber-sumber belajar yang 
dirancang, dikembangkan, dan dimanfaatkan dalam pembelajaran sehingga e-book yang disimpan di handphone dapat merangsang terjadinya proses pembelajaran dalam diri siswa secara mandiri (Ragawanto,2013). E-book inilah yang telah disosialisasikan oleh tim pelaksana dapat membantu siswa untuk dapat belajar secara mandiri dirumah. Keterbatasan waktu belajar tatap muka yang dialami siswa kelas XII dapat teratasi. Selain itu, e-book menawarkan kepada peserta didik, guru dan sekolah terkait dengan media tambahan yang dapat mendukung atau meningkatkan proses pembelajaran. (Embong, dkk, 2012:1802)

Berdasarkan hasil yang diperoleh selama PkM diketahui bahwa pemanfaatan e-book berguna bagi siswa sebagai sumber belajar mandiri di rumah dan di sekolah. Siswa mampu mengerjakan tugas yang diberikan guru meskipun tidak memiliki buku cetak pelajaran berupa cetak. Dengan tersedianya sumber belajar berupa e-book menyebabkan siswa berminat dalam belajar di sekolah. Hal ini mengacu pada pendapat Koriaty \& Manggala (2016) dan Hasbiyati \& Khusna (2017) bahwa e-book dapat meningkatkan minat belajar siswa SMK. Sebelum dilakukan PkM sebanyak 91,7\% siswa tidak memiliki buku cetak mata pelajaran yang lengkap sehingga banyak PR siswa yang tidak dikerjakan dan minat belajar di kelas terganggu.

Rendahnya minat belajar siswa disebabkan karena banyaknya materi yang harus dipahami siswa sementara jam tatap muka di kelas sangat terbatas, kejenuhan siswa dalam penggunaan sumber belajar buku cetak dan materi pembelajaran hanya terpusat pada guru di sekolah. Dengan memanfaatkan $e$-book inilah siswa lebih tertarik belajar karena siswa sudah mampu melakukan belajar secara mandiri menggunakan $e$-book yangn telah dimilikinya.

Pengaruh positif yang miliki siswa disebabkan karena penggunaan $e$-book sebagai sumber belajar mandiri memungkinkan siswa untuk lebih aktif dalam proses belajarnya tanpa bergantung dari penjelasan guru. Hal ini sesuai dengan yang diungkapkan oleh Elain (2002) bahwa pembelajaran mandiri merupakan proses belajar dimana siswa berinteraksi dengan sumber belajar lain selain guru. Dalam hal ini siswa memiliki kebebasan dalam menggunakan gaya belajarnya sendiri, berkembang menurut kecepatan siswa sendiri, menemukan potensi dan bakat dalam siswa sendiri. Sanjaya (2008) menambahkan bahwa optimalisasi hasil belajar dapat terjadi jika terjadi proses interaksi antara siswa dengan berbagai macam sumber belajar selain guru yang mampu merangsang siswa untuk belajar, serta mempercepat pemahaman dan penguasaan bidang ilmu pengetahuan yang dipelajari.

Pemanfaatan e-book sebagai sumber belajar mandiri dapat dipergunakan siswa menjadi salah satu alternatif sumber belajar bagi siswa kelas XII SMA/SMK/MA. Sumber belajar ini terutama dapat digunakan untuk mengatasi kendala keterbatasan waktu yang tersedia untuk pertemuan tatap muka. Dengan memanfaatkan sumber belajar mandiri berupa e-book menjadikan siswa dapat belajar di mana saja, kapan saja sesuai dengan kemampuan dan keperluannya. Senada dengan pendapat Probowo \& Heriyanto (2013) bahwa e-book sebagai buku digital yang memudahkan pelajar supaya dapat membaca ratusan halaman buku hanya dalam satu file dan menghemat biaya membeli buku. Sejalan dengan Letchumanan, Malathi \& Tarmizi, R. A (2010:580) bahwa e-book selalu menarik bagi banyak pembaca sebab sifatnya yang mobile dan fiturnya dinamis. Buku elektronik (e-book) sebagai salah satu publikasi elektronik di masyarakat atau pengguna yang telah mengambil hati dan diterima oleh pembaca sebagai penggunanya.

Selama kegiatan PkM di SMA N 1 Pabelan dan SMK Kanaan, siswa mengaku e-book memiliki keunggulan yaitu : 1) Mudah dibawa. E-book berbentuk softcopy dari buku cetak yang ada sehingga mudah dibawa kemana saja dan dapat dibaca dimana saja. Seperti halnya menurut Siegenthaler et al. (2010) bahwa e-book mudah dibawa yang dapat dibaca menggunakan perangkat elektronik yang menampilkan teks elektronik, 2) Tidak berat. Berapapun banyaknya e-book yang dibawa siswa tidak mempengaruhi berat handphone (tempat menyimapan e-book), 3) Efektif. E-book memiliki berbagai kecanggihan teknologi yang terkandung di dalamnya. Melalui search engine, siswa mampu mencari kata yang diinginkan dan langsung menunjukkan letak kata yang diinginkan. Buku cetak tidak memiliki keunggulan seperti ini. Apabila siswa ingin mencari suatu kata di dalam buku cetak maka cara mencarinya hanya melalui tema kata yang terdapat di daftar isi, 4) Hemat biaya. Siswa dapat mengunduh e-book yang gratis melalui alamat website yang telah diberikan tim pelaksana yaitu http://bukusekolahdigital.com dan http://bsd.pendidikan.id.

Keunggulan di atas didukung dari penelitian Azrai \& Rifrman (2013) bahwa e-book sebagai sumber belajar mandiri dapat dipergunakan guru sebagai salah satu alternatif sumber belajar. Sumber belajar ini terutama dapat digunakan untuk mengatasi kendala keterbatasan waktu yang tersedia untuk pertemuan tatap muka. Dengan memanfaatkan sumber belajar mandiri siswa dapat belajar di mana saja, kapan saja sesuai dengan kemampuan dan keperluannya. Selain itu, keunggulan dari e-book adalah menyukai kenyamanan dari elektronik buku karena tersedia secara online tanpa adanya keterbatasan waktu dan ruang; b. Dengan e-book maka akan mudah untuk men-download dan memiliki sumber belajar mandiri (Wu \& Chen, 2011:297). 


\section{Simpulan dan saran}

Simpulan dari kegiatan ini antara lain : 1) Pelaksanaan PkM pemanfaatan e-book kepada siswa kelas XII SMA N 1 Pabelan dan SMK Kanaan meningkatkan pemahaman terhadap e-book yang ditandai dengan persentase indikator ketercapaian memahami e-book (93\%), mengunduh e-book (51\%), dan menggunakan e-book (80\%), 2) Tanggapan positif dari siswa kelas XII SMA N 1 Pabelan dan SMK Kanaan terhadap pelaksanaan kegiatan PkM ini tergolong sangat baik. Hal ini dapat dilihat dari indikator kehadiran peserta PkM mencapai 98\% dari target dan selama kegiatan berlangsung peserta sangat antusias mengikuti kegiatan dari awal sampai akhir kegiatan, 3) Siswa mengaku e-book memiliki keunggulan : 1) mudah dibawa; 2) tidak berat; 3) efektif; dan 4) hemat biaya.

Adapun saran dari kegiatan ini adalah, ketika melakukan PkM yang menggunakan handphone sebaiknya tim pelaksana menegaskan kembali peraturan kegiatan PkM ketika siswa menggunakan handphone di dalam kelas. Selain itu, siswa diminta tempat penyimpanan/memori internal atau eksternal handphone masih tersedia sehingga ketika proses pengunduhan $e$-book tidak terhambat.

\section{Daftar Rujukan}

Andi Murniati. 2012. "Pemanfaatan E-Journal dan E-Bookoleh Mahasiswa di Lingkungan Fakultas Tarbiyah dan Keguruan UIN Susk Riau". Jurnal UIN Vol 2 No 12012

Azrai, E.P, \& Refirman. (2013). Efektifitas Penerapan e- book sebagai Sumber Belajar Mandiri dalam Pembelajaran Biologi, Prosiding Semirata FMIPA Universitas Lampung, 243-250

Elain, B. , Johnson. (2002). Contextual Teaching and Learning. California: Corwin Press.

Embong, A. M., Noor, M. A., Hashim, H. M., Ali, R. M., Shaari, Z. H. (2012). E-Books As Textbooks In The Classroom. Journal Elsevier: Social and Behavioral Sciences, 47, 1802-1809.

Hasbiyati, H. \& Khusnah, L. (2017). Penerapan Media E-Book Berekstensi Epub untuk Meningkatkan Minat dan Hasil Belajar Siswa SMP pada Mata Pelajaran IPA. Jurnal Pena Sains, 4 (1), 16-21

Koriaty, S. \& Manggala, E. (2016). Penerapan Media E-Book Terhadap Minat Belajar Siswa Di Kelas X Jurusan TKJ SMK Negeri 4 Pontianak. Jurnal Pendidikan Informatika dan Sains, 5(2), 237 - 246

Letchumanan, M \& Tarmizi, R. A. (2010). Utilization Of E-Book Among University Mathematics Students. Journal Elsevier: Social and Behavioral Sciences, 8, 580-587.

Lukman , Bachtiar.2014. PERSEPSI MAHASISWA TERHADAP PENGGUNAAN E-BOOK \& E-LIBRARY (STUDI KASUS PADA SCIENCE DIRECT) . Jurnal Fakultas Ilmu Komputer, Universitas Darwan Ali Vol 2 No 12014.

Munif, A (2013). E.Book dan Buku Teks. Jakarta, Pustaka Setia.

Prabowo, A. \& Heriyanto. (2013). Analisis Pemanfaatan Buku Elektronik (E-Book) oleh Pemustaka di Perpustakaan SMA Negeri 1 Semarang. Jurnal Ilmu Perpustakaan. 2 (2), 1-9

Ragawanto, S. T. (2013). Pengembangan Media Web Moodle Pada Mata Pelajaran Produktif Teknik Komputer Dan Jaringan Bab Mendiagnosis Permasalahan Pengoperasian PC dan Periferal untuk Siswa Kelas X TKJ di SMK Negeri 1 Surabaya. Jurnal Mahasiswa Teknologi Pendidikan. 1 (3), http://jurnalmahasiswa.unesa.ac.id.

Ramli Abdullah.2012."PEMBELAJARAN BERBASIS PEMANFAATAN SUMBER BELAJAR". Jurnal Ilmiah DIDAKTIKA Februari 2012 VOL. XII NO. 2, 216-231

Rosida, Noor Fadiawati, Tri Jalmo.2016."Efektivitas Penggunaan Bahan Ajar E-Book Interaktif Dalam Menumbuhkan Keterampilan Berpikir Kritis Siswa". Jurnal IPA FKIP Unila Vol 2 No 32016

Sanjaya, W. (2008). Perencanaan dan Desain Sistem Pembelajaran. Jakarta, Kencana. 
Siegenthaler, E., Wurtz, P. \& Groner, R. (2010). Improving the Usability of E-book Readers. Journal of Usability Study, VI (1), 26.

Suwarno , W. (2011). Perpustakaan dan Buku : Wacana Penulisan dan penerbitan. Yogyakarta, Ar-Ruzz Media.

Wu, M. \& Chen, S. (2011). Graduate Students' Usage of and Attitudes Towards E-Books: Experiences from Taiwan. Program: Electronic Library and Information System, 45 (3), 294-307. 